\title{
The Consequences of Ambiguity: Designing and Implementing the ESSN
}

\begin{abstract}
The stated purpose of the Emergency Social Safety Net (ESSN) was to contribute to meeting the basic needs of the most vulnerable refugees in Turkey. In the context of this book's argument, we ask whether it achieved this goal but also whether and to what extent it contributed to extending elements of market citizenship to forced migrants. We conclude that while the ESSN's CT program made a limited contribution to meeting basic needs and empowering displaced persons as consumers, other elements of market citizenship, or even "denizenship," are lacking. With regard to its explicit targets, the effectiveness of ESSN was limited by the ambiguities of its design, linked to the different priorities of the agencies involved, which exclude some vulnerable persons from the program. More broadly, very limited access to the formal labor market remained an obstacle to fuller market citizenship.
\end{abstract}

Keywords Turkey $\bullet$ European Union $\bullet$ Syria $\bullet$ Refugee policy $\bullet$ ESSN - Outcomes

As detailed in the previous chapter, the humanitarian response to the emergency created by the mass forced migration of Syrians to Turkey, and the Emergency Social Safety Net (ESSN) cash-transfer (CT) program in particular, were inextricably tied to the security-centered provisions of the broader EU-Turkey agreements. The ESSN, we concluded, is best

(C) The Author(s) 2021

C. Ark-Yıldırım, M. Smyrl, Social Cash Transfer in Turkey, https://doi.org/10.1007/978-3-030-70381-3_6 
understood as the product of an ambiguous consensus, in which the various parties agreed on the creation of a policy instrument, but did so for different reasons and with different medium-term ends. In this chapter, we explore the consequences of ambiguity. We note in particular that it contributed to important departures from the logic and ideals of market citizenship. Particularly important were security-based restrictions on participation and an approach to determining need based on indicators generally recognized as imperfect. All of these, call into question the capacity of ESSN to function as a "citizenship approach to poverty" (Leisering 2019) even in the limited sphere of market integration and Marshallian "social citizenship." In ongoing debates concerning the program's future, as seen in the chapter's final section, we find further evidence that the underlying ambiguities inherent in its creation have yet to be resolved. Critical among these are tensions among policy agendas of various Turkish agencies focused, respectively, on incorporating Syrians under Temporary Protection (SuTP) into the Turkish economy, maintaining EU financial engagement for their social support, and encouraging repatriation to Syria.

\section{l From Uncoordinated Initiatives to the ESSN}

The ESSN, when it was established in 2016, built on the experience and incorporated tools and procedures pioneered by an earlier generation of CT programs for forced migrants. The order-of-magnitude increase in scale of budget and beneficiaries led to significant modification to this starting point, and generated procedures that marked the program throughout its existence.

\subsection{CT Programs in the Initial Responses to the Syrian Emergency}

Cash assistance to out-of-camp refugees prior to 2015 was provided largely by NGOs, but was often patchy geographically, and ill-coordinated. ${ }^{1}$ The Support for Life Association, a secular humanitarian NGO based in Turkey, implemented a CT program reaching approximately 54,000 households from 2012 to 2016 (Yilmaz 2019: 728). The Danish Refugees Council distributed cash voucher to refugees in Şanlıurfa and Hatay in 2014-2015. From an organizational standpoint, however, the most direct precursor of the ESSN was a program put in place for in-camp refugees by

\footnotetext{
${ }^{1}$ Interview, 2019
} 
the Turkish Red Crescent (TRC) from 2012 to 2016. Its origins go back to 2007, when the TRC started to distribute food packages collected from donors wishing to honor the religious requirement to provide an offering (zekat) for breaking of the fast to the needy at the end of Ramadan. This initiative soon encountered logistical problems typical of in-kind distribution. Food packages are heavy, around $20 \mathrm{~kg}$, which created problem of transportation and increased the need for distribution personnel. In 2011, TRC created the zekat kart (alms card) for Turkish citizens to replace food packages. ${ }^{2}$ This program was subsequently extended to Syrians. An important decision taken at the outset was to use a newly created vehicle the Klzlaykart (Red Crescent Card) for this purpose, rather than the existing zekat kart. Like the national PTT card, the Klzllaykart makes use of the capacity of chip-enabled smart cards to access multiple cash assistance program at the same time. Operations began in October 2012 as a pilot in-camp food assistance project in partnership with World Food Program (WFP), AFAD, and Halkbank. ${ }^{3}$ Through this program, 65 TL per family member per month was provided via the Klzllaykart to all persons in the camp, without any additional conditions. The Kilis Öncüpınar camp was chosen as location for the pilot project because the camp was built out of containers, not tents, which did not allow expansion and kept the population stable. The program was extended to 14 camps as of July 2013 , functioning as an e-voucher, with three shops designated in each camp and equipped with POS machine for payment. ${ }^{4}$ Initially, AFAD determined the shops where money could be spent; WFP transferred the funds, TRC distributed the Klzllaykart, and Halkbank produced the cards and inserted them into its financial systems.

In addition to addressing supply-side problems such as food spoilage that are typical of food distribution, the Klzlaykart helped to resolve demand-side issues such as cultural and dietary differences. After a year of regular but monotonous food distributions, these were near to causing revolt in the camps especially in Karkamış and Altınözü. ${ }^{5}$ An out-of-camp version of the program was launched in May 2015. The new plan was funded by WFP in four cities: Hatay, Antep, Urfa, Kilis, and then expanded to two more Osmaniye and Maraş. The Klzllaykart at that time functioned

\footnotetext{
${ }^{2}$ Interview, 2020

${ }^{3}$ Halkbank (people's bank) is a public-private partnership of which the Turkish state owns a majority share.

${ }^{4}$ E-vouchers enable recipients to make purchases up to the value of the voucher and are often for one-off use in designated stores, within a specified time frame.

${ }^{5}$ Interview, 2019.
} 
as in the camps: usable only in designated shops. ${ }^{6}$ Between 2015 and 2017, out-of-camp assistance was provided to approximately 300,000 refugees $(160,000$ from the WFP/TRC out-of-camp Kizılaykart and 140,000 through other NGO programs) (Maunder et al. 2018: 18).

\subsection{Establishment and Implementation of the ESSN}

An immediate outcome of the FRiT was a major reorganization of the actors and instruments of humanitarian assistance in Turkey. The establishment of the ESSN was intended to bring about not only an increase in the absolute amount of assistance but a consolidation and rationalization of these diverse initiatives. ${ }^{7}$ The result was the largest single program to come out of the FRiT, indeed the largest humanitarian project ever funded by EU. As stated in its program documents, the purpose of the ESSN was to contribute to ensuring refugees' access to basic needs (food, non-food items, and services). A requirement of DG-ECHO from the outset was to use cash assistance as a vehicle of aid. Unrestricted and multipurpose cash was preferred to food vouchers or other more limited forms of assistance. ${ }^{8}$ While not applicable to all situations, this was considered appropriate in Turkey because two critical conditions were met:

- Supply and distribution of basic needs items was not a problem

- There was a robust financial system in place (large banks with extensive ATM networks)

The instrument selected as a vehicle for CT was the preexisting Klzllaykart, which was transformed as a result from a de facto e-voucher into an instrument for multipurpose cash. The choice of this vehicle was symbolically important, as a sign that programs for Turks and those for migrants remained distinct. ESSN payments are made using the Klzllaykart by agreement with Halkbank, contracted by the TRC (Maunder et al. 2018). The TRC was put forward as the public face of this new program to avoid criticism by Turkish citizens for giving money to Syrians. ${ }^{9}$ Using the PTT card, universally identified with Turkish public programs, might

\footnotetext{
${ }^{6}$ Interview, 2020.

${ }^{7}$ Interview, 2019.

${ }^{8}$ Interview, 2020.

${ }^{9}$ Interview, 2020.
} 
create tension. Indeed, our experience of participant observation with TRC and WFP teams produced anecdotal examples of this sentiment from Turkish citizens encountered during the visits. Even the distinction between the two cards, let alone between Turkish and EU funding was not clearly understood, with several people expressing indignation that the TRC was helping Syrians rather than Turks. ${ }^{10}$

As of 2020, the Kizllaykart had become the common platform for a number of assistance programs. In addition to the ESSN, the card was used for targeted programs such as Conditional Cash Transfer for Education, which was launched in May 2017 and Adult Language Training was launched in 2019. It also kept its original function, dating back to 2012, as a vehicle for in-camp food assistance.

\begin{tabular}{ll}
\hline Program & Participants as of February 2020 \\
\hline In-Camp Food Assistance Program & 54,700 \\
ESSN & $1,707,486$ \\
CCT for education & 608,082
\end{tabular}

Source: Red Crescent Report February 2020 (http://platform.kizilaykart.org/tr/Doc/rapor/ KIZILAYKART_TR.pdf)

The operational rules of DG-ECHO imposed a number of the central design features of the ESSN. One of these, as discussed in Chap. 5, was the multiagency nature of the program. While DG-ECHO, acting in the name of the FRiT trust fund and its steering committee, played the role of the funding agency, implementation was delegated to the WFP in partnership with the TRC. These, in turn, worked closely with Turkish authorities at both the national and local levels. Although it remained distinct, the ESSN was embedded in the infrastructure of Turkish national social assistance. The National Integrated Social Assistance System (ISAIS), managed by the Ministry of Family, Labor, and Social Services (MoFLSS) became the national database of all ESSN participants. The 1,003 local Social Assistance and Solidarity Foundations (SASF) were the frontline agencies, processing applications and carrying out inspection visits. ${ }^{11}$

For practical reasons, the procedure for ESSN could not be identical to that used with Turkish citizens. For citizens, information about income

\footnotetext{
${ }^{10}$ Participant observation 2020.

${ }^{11}$ https://www.ailevecalisma.gov.tr/sygm/genel-mudurluk/sosyal-yardimlasma-ve-dayanismavakiflari/.
} 
(from official employment) and assets are already in the SAIS, allowing SASF boards, as we saw in the case of $\mathrm{R}$, to assess applicants with respect to a predetermined "poverty threshold." For refugees, whose income cannot always be determined from data in the ISAIS as they may have income or assets outside of Turkey, the conditionality requirement of being unemployed was retained. Those employed with a valid work permit or who own registered assets in Turkey are formally ineligible to receive assistance (WFP 2019a: 1). How strictly this prohibition was followed is not clear; one official of the WFP interviewed acknowledged it but noted that "we will give it less importance." 12

As with the domestic CT programs discussed in previous chapters, the operational logic of the ESSN is one of needs-based targeting. In a context of imperfect and incomplete information about actual needs, however, the best that could be done was to establish observable indicators of vulnerability. Families wishing to participate in the program were required to submit an application form to the SASF of the district in which they are registered or, in certain districts where the Syrian population is particularly concentrated, to special offices set up by the TRC.

Formally, eligibility was determined by an assessment of economic vulnerability based on six demographic criteria, any one of which was considered sufficient to qualify a family without employment for ESSN.

- Elderly headed households if no other adults are present

- Single headed household with at least one child under 18

- Single women

- Families with 4 or more children

- Families with 1 or more disabled members (at least $40 \%$ disability)

- Families with a dependency ratio of 1.5 and above

The decision as to whether a family meets one or more of these criteria was taken by the board of trustees of the district SASF. Families who qualified through the demographic criteria were subsequently visited by home inspection teams from the SASF, as in the case with Turkish families requesting social assistance.

${ }^{12}$ Interview, 2019. 
As of early 2020, the ESSN was used by over 1.7 million beneficiaries, selected from a pool of 2.7 million applicants. ${ }^{13}$ A great majority (89\%) of these is Syrian, but other nationalities are present as well: Iraq (6.9\%), Afghanistan (3.4\%), and Iran (0.2\%). In light of these numbers, and of the fact that the Syrian migration was the precipitating event for the creation of ESSN there is a tendency, which we share, to refer generally to ESSN recipients as SuTP or simply "Syrians." Just over half, (51.3\%) are women (IFRC July 2020). The population of beneficiaries is predominantly young, with $60 \%$ under 18 . Persons $18-59$ years of age make up $37 \%$ of beneficiaries, while those 60 and over are only 3\% (IFRC 2020). Of families receiving the card, the largest number qualified through having at least four children (41.7\%) followed by families with a dependency ratio above 1.5 , which make up $26.3 \%$ of households. Households with single-parent families with no other adults living in the household make up 14.13\%. Households with at least one disabled person make up 9.2\% of beneficiaries (IFRC, July 2020). Some families may fall into more than one of these categories. An additional 7.497 households, or $2.4 \%$ of the total, live in families that do not fit the formal demographic criteria and are included at the discretion of local Social Assistance and Solidarity Foundation (IFRC, July 2020). The largest number of participants was found in Gaziantep (13.9\%), Istanbul (12.2\%), and Şanliurfa (10.2\%). The total amount spent on the ESSN Program had reached $€ 1.4$ billion as of June 2020 (TRC 2020 ) out of a potential budget of $€ 1.725$ billion. $^{14}$

Participants in the program received the Klzllaykart, topped-up each month by $120 \mathrm{TL}$ per family member. ${ }^{15}$ Beneficiaries may receive an additional quarterly payment. For families that include severely disabled persons, this payment was 600 TL (WFP 2019b). The card could be used at any ATM machine in order to withdraw cash or to make purchases using a point of sale (POS) machine. The beneficiaries of each card were registered and identified by name. The identity of the cardholder was verified

\footnotetext{
${ }^{13}$ Except as otherwise noted, all data in this paragraph are taken from the Turkish Red Crescent Refugee Center Directorate Report, February 2020. http://platform.kizilaykart. org/en/Doc/rapor/ESSN_ENG.pdf. http://platform.kizilaykart.org/en/Doc/rapor/ ESSN_ENG.pdf

${ }^{14}$ https://ec.europa.eu/commission/presscorner/detail/en/QANDA_19_6212

${ }^{15} \mathrm{See}$ introduction for discussion of currency conversions. For the reasons set out there, we continue in this chapter the practice of defining assistance payments exclusively by their value in TL.
} 
initially by a physical check and then monthly by telephone. ${ }^{16}$ Each month the MoFLSS updated its list of beneficiaries. A WFP/TRC Joint Management Cell checked this for any problem, such as double registration. The card was blocked if an attempt was made to use it outside the country or if the monthly check did not confirm the presence of the cardholder. The card could also be canceled if it went unused for 6 months or more. Once the list was verified every month, it was forwarded to Halkbank for payment. ${ }^{17}$

The ESSN's immediate objective as stated by a 2018 independent evaluation report produced for the WFP was to "stabilize or improve living standards of the most vulnerable out-of-camp refugee households" (Maunder et al. 2018: iv). By this standard, the report found positive outcomes:

ESSN beneficiaries are better off in terms of food security as measured by their food consumption score, while the food security of non-beneficiaries has declined. Debt has reduced after transfer for beneficiaries, with average debt per adult equivalent falling by TL 57 among beneficiaries and rising by TL 81 among non-beneficiaries. (29)

The distinction made between beneficiaries and non-beneficiaries, however, suggests an obvious question: why are families with deteriorating nutrition and rising debt not included in the program? The reasons for this, it turns out, were embedded in design elements of the ESSN to which we turn our attention in the following section.

\section{Who is Eligible? Problems of Registration AND TARGETING}

On the most immediate level, the ESSN clearly made an important positive contribution. But did it meet its larger goals? As expressed by the WFP:

WFP Turkey's Transitional Interim Country Strategic Plan builds on WFP's partnership with the Government of Turkey and other stakeholders to contribute to refugee households' ability to meet their basic needs, ensuring no vulnerable refugee is left behind. (WFP 2019b)

\footnotetext{
${ }^{16}$ https://ec.europa.eu/commission/presscorner/detail/en/QANDA_19_6212

${ }^{17}$ Interview, 2019.
} 
More generally, as set out in the EU-Turkey Joint Action Plan (JAP), the broader effort of which it was a part sought to promote integration of SuTP through "the enhancement of self-sufficiency and participation in the economy and their social inclusion during their stay in Turkey" (European Commission 2015: 1). This objective brings us back to our central question: do CT instruments contribute to market citizenship? The situation of SuTP, we have argued, presents a particularly challenging test for the hypothesis that they might do so, since this is a case in which elements of Marshallian social citizenship would be provided in the absence of civil or political citizenship. Our discussion of "denizenship" in Chap. 2 suggests that this is not impossible, but did it happen in this case?

We suggest in the pages that follow that a number of obstacles have hindered progress in this direction. Central among these is the political imperative behind the 2015 deal, which was to stop the flow of undocumented migrants into the EU. The result of these original conditions can be seen in two of the program's central features, the dependence on demographic criteria for eligibility and the link between eligibility and registration. Each has proven to be a barrier both to the short-term goal of "ensuring no vulnerable refugee is left behind" and to the broader objectives of social and economic inclusion set out in the JAP. These barriers are not a question of "theory and practice" or of "implementation failure" but, just as in the local cases studied in Chap. 4, of program design. In this context, the ESSN's shortcomings are just as instructive as its successes. Both help to improve our understanding of the requirements for CT to contribute meaningfully not just to short-term survival but more importantly to broader and more sustainable social integration as a "citizenship approach to poverty" (Leisering 2019).

\subsection{Enforcing Security Priorities through Registration}

Ensuring that migrants did not attempt to enter Europe required that they be identified and fixed in place within Turkey. The requirements of the ESSN reflect this political imperative. Two distinct types of official registration are required in order to be eligible for $\mathrm{ESSN}^{18}$ :

- All family members must be registered under temporary or international protection status.

${ }^{18}$ https://docs.wfp.org/api/documents/WFP-0000104792/download/ 
- All family members must have a residence registration in a city where they are permitted to live. ${ }^{19}$ If members of the family are registered in different cities, they are not allowed to get ESSN. To obtain residence registration, families must prove that they have a legally recognized address.

Prior to 2016, the Turkey-Syria border could be freely crossed. The procedure for Syrians seeking TPS was to approach the Provincial Directorate of Migration Management (PDMM) in the province where they settled. Applicants were asked to submit any available Syrian identity documents. In the absence of documents, Turkish authorities would provide registration based on the testimony of protection seekers (Özer 2015; Batalla and Tolay 2018) According to Baban et al. (2017: 91) the registration process was initially "chaotic" as different government offices applied "contradictory criteria" in registration, and the speed of registration varied among government offices. In the summer of 2015, the Turkish government sought to address this by issuing new identity cards for migrants, which caused delays in registration.

A major change to this process came in 2016, when Turkey moved to close its borders and imposed visa requirements for all persons coming from Syria, as well as to citizens of 18 additional countries entering into Turkey by air or sea. ${ }^{20}$ The border closing was an explicit provision of the 2015 EU-Turkey Joint Action Plan (JAP), which stated that:

In line with the Visa Roadmap requirements, pursue the progressive alignment of Turkish visa policy, legislation and administrative capacities notably vis-àvis the countries representing an important source of illegal migration for Turkey and the EU. (European Commission 2015)

The registration of migrants into the Turkish migration system is also required under the JAP. The March 2016 EU-Turkey statement emphasized the "achievement" of Turkish border control implementation such as "the introduction of new visa requirements for Syrians and other

${ }^{19}$ Migrants with International protection status, can live only in so-called satellite ci,ties according to the regulation of the implementation of LFIP article $3 / \mathrm{hh}$. These are 51 small Turkish cities, which are outside of Istanbul, Ankara, and Izmir.

${ }^{20}$ Afghanistan, Bangladesh, Cameroon, Congo, Democratic Republic of the Congo, Eritrea, Ghana, Ivory Coast, Mali, Myanmar, Nigeria, Pakistan, Somalia, South Africa, Sri Lanka, Sudan, Uganda. https://www.avrupa.info.tr/sites/default/files/2016-12/third_ progress_report_on_turkey_visa_liberalisation_roadmap_en_0.pdf 
nationalities, stepped up security efforts by the Turkish coast guard and police and enhanced information sharing." Construction of a border wall began in 2016 and was completed in June 2018 (Batalla and Tolay 2018).

The 2016 migration reform also brought changes for SuTP already in Turkey. The registration process changed again and new restrictions on mobility were applied. According to this change, Syrians will get services and assistance only in the city where they were registered. Persons wishing to change their province of residence must apply to the provincial directorate of migration management in the province where they first registered in order to obtain permission to move to another. They must then apply to the PDMM of the new province to obtain a new ID card (Baban et al. 2017). Unauthorized travel can cause cancelation of status and loss of rights to social assistance. ${ }^{21}$

For families seeking assistance from the ESSN, registration under the rules of temporary or international protection is only a first step. Eligibility for the ESSN also requires all members of applicant families to have a legal proof of address in a single location. Obtaining this requires that the residence itself be recognized by local authorities. This poses a serious problem for those who cannot register their address into Turkish System. As a WFP grassroots official indicated to us, refugees who cannot afford to pay formal house rent and are living in informal housing without an official street address and/or not officially recognized by authorities as residential property. ${ }^{22}$ WFP data suggests that such informal lodging includes tents, containers, unfinished buildings, shops, warehouses, and even caves (WFP 2017). Solutions to problems like this can only come from circumventing the system: according to another WFP official, local authorities will sometimes assign addresses to refugee families in order to allow them to register. However, this is dependent on local authorities' willingness. ${ }^{23}$

Changing address poses a challenge. TRC puts payments on hold until the new address has been validated. This can force refugees to put up with abusive landlords or rent increases in order not to lose benefits (Maunder et al. 2018). Further complicating the situation, Istanbul and nine Syrian borders' cities_-Adana, Gaziantep, Kahramanmaraş, Kilis, Mardin, Mersin, Osmaniye, Şanlıurfa, and Hatay—stopped registering new refugees in late

\footnotetext{
${ }^{21}$ https://www.ntv.com.tr/turkiye/suriyelilere-yol-izin-belgesi-uyarisi-Jdnxk5PTCkq TKOx6q7-KyA

${ }^{22}$ Interview, 2019.

${ }^{23}$ Interview, 2019.
} 
2017 or early $2018 .{ }^{24}$ Even for those already registered elsewhere in Turkey, relocating to Istanbul was stopped in $2018 .{ }^{25}$ Citing the increasing population, the Istanbul Governor's Office announced that people under temporary protection registered elsewhere than Istanbul province needed to return to other provinces where they are registered no later than 20 August 2019. ${ }^{26}$ According to the governor of Istanbul, this resulted in the departure of 97,255 Syrians from the city. ${ }^{27}$

The negative consequence of registration requirements on the ESSN's ability to reach all of the most vulnerable refugees is recognized by both the EU and the WFP:

The programme did not sufficiently anticipate the challenges that unregistered households - who are also some of the most vulnerable - would face in becoming registered or include activities to address this. (Maunder et al. 2018: 18)

...despite substantial support to partners providing services directly (as a complement to the large programmes using government systems), DG ECHO has not been able to ensure full service coverage to a significant portion of the refugee population which is either unregistered, or registered and living outside its provinces of registration. (DG-ECHO 2019: ix)

From our perspective, two broader observations are relevant. The first, as we have argued, is that the registration requirements that proved problematic from a humanitarian perspective were an integral part of the program's larger rationality. The second is that the restrictions on movement are antithetical to a fundamental principle of market citizenship. Returning to Sen's (1981) logic of market entitlements, we noted in this book's introduction that restrictions on what one can buy, where one can live, or whether and how one can work are barriers to market inclusion. The

\footnotetext{
${ }^{24}$ https://www.hrw.org/news/2018/07/16/turkey-stops-registering-syrian-asylumseekers

${ }^{25}$ https://www.hurriyetdailynews.com/turkish-government-stops-relocating-syrians-toistanbul- 127084

${ }^{26}$ https://www.hurriyet.com.tr/gundem/istanbul-valiliginden-suriyeliler-ile-ilgili-onemli-aciklama-20-agustosa-kadar-sure-41281036. Implementation of this decision was not applied fully during the Covid-19 crisis, resulting in toleration of SuTP who would otherwise have been sent away from Istanbul province, but public assistance remains denied to such persons. (Interview, 2020)

${ }^{27}$ https://www.hurriyet.com.tr/gundem/istanbul-valisi-acikladi-97-bin-255-suriyeliistanbuldan-ayrildi-41412205
} 
central place of such restrictions in the system design of the ESSN attests to the ambiguity of its inception: security concerns-both Turkish and European-influenced the life chances of refugees as or more than the JAP's commitment to "the enhancement of self-sufficiency and participation in economy and their social inclusion during their stay in Turkey" (European Commission 2015: 1).

\subsection{Identifying the "most vulnerable" through Demographic Criteria}

A distinct issue in the design of the ESSN is the way in which assistance is allocated among those who have fulfilled the registration requirements discussed above. There are two distinct questions here: the decision to target aid to the "most vulnerable" rather than providing it to all registered refugees, and the specific means by which targeting is carried out. The first of these brings us back to the largely theoretical debate between the partisans of universal basic income and those of means-tested assistance. For the former (Buğra and Adar 2008), any deviation from undifferentiated treatment for all constitutes an affront to a rights-based model of ideal citizenship. The approach taken in practice by the "safety net" programs of Europe and North America relies on a different understanding of universality, understood as a "right to protection against poverty" as opposed to a "right to a given benefit" (Leisering 2019: 57). Meanstested programs can, in this view, be conducive to social citizenship if they are targeted to those who need them most. How this targeting should be done, however, is not self-evident. In the case of the ESSN, it posed a number of practical problems.

The term "vulnerability" as a determinant of priority for assistance recurs in all official descriptions of the ESSN, whether from the EU or the implementation partners. The way in which vulnerability is determined, however, is an artifact of the program's history. The assessment report prepared for the WFP states that: "the scale of the refugee crisis in Turkey and the objective of rapidly scaling-up to reach over a million refugees meant that the targeting approach needed to be capable of identifying a large a number of refugees in a short timeframe" (Maunder et al. 2018).

The EU's final evaluation report details the initial informational challenges faced: 
DG ECHO and its partners planned and implemented their initial projects with limited data and severe time constraints. The only planning information available in early 2016 was a dated disaster and Emergency Management Presidency of Turkey (AFAD) study from 2013, and a patchwork of thematic or local academic studies and NGO surveys, none of which provided a full picture or at a level of detail useful for design and implementation of a large programme. Specifically, there was little disaggregated data available on women, children, elderly and disabled people. The EU's Facility Needs Assessment (2016), itself decries the lack of data: "the lack of comprehensive data that has been collected and/or shared on demographics and vulnerabilities is also a serious hindrance to assessing needs and designing programs and interventions.” (DG-ECHO 2019: 13)

Even the initial scaling-up of the program was complete, the same assessment estimates that the "exclusion error" attributable to the use of the demographic criteria was on the order of $5 \%$ (14).

In principle, it might have been possible to overcome this imperfect targeting through direct inspection. For Turkish citizens, as we saw in the case of R, eligibility is based on individual assessment using both nationally determined objective criteria-information in the ISAIS database and the "poverty score" calculated for each family—and locally organized onsite inspection carried out by the district SASF. An analogous procedure of on-site inspection was included in the design of the ESSN, with local SASFs once again tasked with carrying it out. An advantage attributed to this system by national officials, as we noted in the previous chapter, is the local knowledge provided by this decentralized system.

In practice, two important differences were evident between procedures used for the ESSN and those for domestic policy. In the first place, initial assessments of eligibility depend for the most part on the demographic criteria, since the ISAIS does not contain complete information about refugees' income or assets, and thus cannot be used to generate a "poverty score." The only information initially available through the ISAIS is whether refugees have a valid Turkish work permit or own property in Turkey, either of which eliminates them from ESSN eligibility (European Commission 2019: 3). Home visits for ESSN recipients were postponed until after they began receiving benefits - within 12 months of registration in order to ease the burden on the foundations (Maunder et al. 2018: 12). According to grassroots staff of the WFP, some foundations do not carry out house visits at all, but instead summon the family 
for an interview in the office of the SASF. ${ }^{28}$ Moreover, despite the presence of translators, cultural distance between Turkish social workers and forced migrants is necessarily greater than in the case of domestic programs. This goes beyond questions of nationality or language; the life experience of a long-term low-income resident of a Turkish community is self-evidently different from that of a family that has just gone through war and forced international migration. It seems reasonable to suggest, accordingly, that the advantage of using local agencies to assess vulnerability is less in the case of forced migrants than for domestic populations, or at the very least that significant differences may exist among local SASFs in this respect. ${ }^{29}$

For families denied assistance, there is no formal appeals process: the only option is to begin a new application (Maunder et al. 2018: 28). Claimants were not left entirely to their own devices, however. An informational call center was maintained by the TRC. While TRC staff could not revisit the decisions made by the SASF boards, they could advise claimants on how best to reapply and, in some cases, intervene on their behalf directly with the MoLFSS. If foundations reject applicants without examination, the ministry can intervene and advise the SASF to reconsider. ${ }^{30}$ The boards have the final say in their districts, however; the ministry can only advise. According to the IFRC website, as of April 2020, TRC's ESSN hotline answered 1.2 million calls, sent more than 1.3 million SMSs and reached out to more than 85,000 refugees thorough its multilingual Facebook page. ${ }^{31}$

Even in the absence of any appeal mechanism, solution can sometimes be found in order to overcome problems of eligibility. DG-ECHO estimates an "exclusion error" of $5 \%$ and provides a discretionary allowance to district SASFs (DG-ECHO 2019: 14). This was created explicitly in order to find a solution to the problem that some vulnerable families would be excluded by the formal process. As of 2018 , boards of trustees can decide to include some households (up to $5 \%$ of the total number of applications received by that SASF) that do not meet the demographic criteria (Maunder et al. 2018; TRC 2018). From the perspective of national authorities, however, this did not constitute an absolute right for

\footnotetext{
${ }^{28}$ Interview, 2020.

${ }^{29}$ Interview, 2020.

${ }^{30}$ Interview, 2020.

${ }^{31}$ https://media.ifrc.org/ifrc/2020/04/28/5-ways-cash-assistance-transformed-humanitarianresponse-refugees-turkey/.
} 
claimants; as noted earlier, eligibility determination remained under the authority of SASF boards, who could choose not to use it, leading to variation from one Foundation to another. For the frontline representatives of the WFP, failure to use the additional discretionary amount presented a problem. "When we see that they are not using their discretionary allowance, we open an issue." ${ }^{2}$ National-level officials had a different view, pointing out that it was important for the local foundations to maintain a reserve in the case of increased local demand. It was mistaken, in their opinion to consider the $5 \%$ as a target to be met. ${ }^{33}$ It remains, however, that the $5 \%$ discretionary allowance is neither a legal target for foundations nor a right for recipients. Its use is left to the judgment, or eventually the compassion, of the program's implementors.

At an anecdotal level, stories of perceived inequities are easy to find. Although he personally was an ESSN beneficiary, a man encountered during one of our participant observations indicated that "the real needy cannot get assistance." One Syrian woman ESSN beneficiary indicated her vulnerability by explaining:

\section{I could not get card for a long time because I did not have a fourth child. I had difficulty to find enough to eat for me and my children. However, they did not give us the card. After, I had my fourth baby I got assistance. I was vulnerable at the time before this new baby. I should get the assistance at that time. I do not think that all vulnerable people benefit from this. ${ }^{34}$}

From the perspective of this woman, many necessary expenses such as utility bills and rent are constant and not related with the number of refugees. For those in the program, this issue is taken into account by the quarterly top-ups, which are proportionally larger for smaller families. ${ }^{35}$ This cannot be applied, however, to a person such as this woman who does not qualify in the first place.

Beyond individual stories, a general limit to all such solutions is that they treat refugees not as holders of rights but as victims needing charity. The resulting logic of paternalism brings us back to our initial discussion of the justification for moving toward market-enhancing instruments of social support in the first place. These were meant to break the practice of

\footnotetext{
${ }^{32}$ Interview, 2020.

${ }^{33}$ Interview, 2020.

${ }^{34}$ Participant observation, 2019.

${ }^{35}$ Interview, 2019.
} 
individuals being treated as helpless "pawns" by the all-powerful (even if altruistic) "knights" of the welfare state bureaucracy (Le Grand 2003). The blurred lines between state and nonstate actors in the case of ESSN do not obscure the fact that the "knights" are back in charge. Strengthening the elements of market citizenship in CT policy would require moving toward a regime with less scope for arbitrary decision. If we follow Leisering's (2019: 57) logic of "universal protection against poverty," promotion of equal rights is not incompatible with means-testing and targeting benefits to the most vulnerable, but it would require these to be identified in a more objective manner.

\section{From Ambiguous Consensus to Uncertain Future}

We noted in Chap. 5 that the lines between humanitarian assistance and domestic social support are increasingly blurred. The case of ESSN illustrates that the reasons for this go well beyond the pragmatic altruism of the "New Way of Working." Political context has a direct impact on policy design. The limits on eligibility explored in the previous section are direct consequences of this: a product of the short-term consensus that led to an instrument necessarily addressing both humanitarian and security concerns.

As the agreed programming period for the FRiT and the ESSN came to an end, unresolved questions at a more fundamental level emerged anew. Differences of interest between Turkey and the European Union are only the most obvious of these. Also important are ongoing tensions between different understandings of humanitarian assistance and, in particular, on what constitutes an "emergency." Differences in priority were also evident among and within various Turkish and European agencies with respect to what form an "exit strategy" from ESSN should take. From ongoing debates at the time of this book's writing, in the autumn of 2020, three possible scenarios could be discerned: one for continuing CT and two for transitioning away from it. For beneficiaries, however, what mattered most was the ongoing uncertainty perpetuated by the underlying divergences in priorities and principles among decision-makers.

\subsection{CT as an Ongoing Necessity}

As of the summer of 2020 , virtually all of the $€ 6$ billion total budget of the FRiT had been committed. With the Syrian-Turkish border effectively 
closed, the number of registered SuTP in Turkey was no longer increasing. ${ }^{36}$ Did it follow that the emergency was over? From the perspective of DG-ECHO, the structure of ESSN mandated that the program be temporary. Faithful to this logic, DG-ECHO was preparing to end its role in the program by the end of 2020 .

\begin{abstract}
In line with long-standing humanitarian policies to promote local integration as a durable solution to displacement and more recent Turkish commitments to refugee solutions, DG ECHO's exit strategy is premised upon the GoTR taking on (or continuing) service delivery, in some sectors with support from $D G-N E A R$, and eventually integrating refugees fully within Government systems. (DG-ECHO 2019: 20)
\end{abstract}

The support alluded to in this document took the form of a "top-up" of the ESSN from the EU's 2020 budget (with the IFRC replacing the WFP as the implementing agency), followed by a grant to the Turkish MoFLSS of $€ 245$ million for continuation of social support to SuTP to begin in January 2021. In both cases, DG-NEAR was the designated EU funding agency. ${ }^{37}$ What if any EU funding might follow this was uncertain. What seemed clear, on the other hand, was that ongoing support for forced migrants would be necessary into the indefinite future.

Our interviews, carried out in 2019 and 2020, found Turkish officials insisting on the importance of continued budgetary burden-sharing from the EU and contesting the relabeling of humanitarian assistance as development aid. The clear, and unacceptable, implication of this shift in European vocabulary, from this perspective, was a significant decrease in financial support. ${ }^{38}$ This sentiment was acknowledged in Brussels: "We have a plan and a transition strategy. The Turks didn't like this because transition implies exit, and end of EU support which they do not accept." 39

In the short term, the "transition strategy" proposed took the form of a support program modeled on the ESSN and using the same instrument, but aimed at beneficiaries deemed incapable of integration into the labor market. Significantly, there was disagreement between the EU and Turkish authorities as to what this program should be called. Officials of DG-NEAR,

\footnotetext{
${ }^{36}$ https://data2.unhcr.org/en/situations/syria/location/113

${ }^{37}$ Interview, 2020. The "top-up" amount was to be on the order of $€ 485$ million to be divided between ESSN and the Conditional Cash for Education program.

${ }^{38}$ Interview, 2020.

${ }^{39}$ Interview, 2020.
} 
who would be called on to administer it from the European side, referred to it as a "direct grant" to the Turkish government, thus marking the distinction with the original ESSN and its indirect funding mechanism and emphasizing the goal of eventually integrating aid to forced migrants into the Turkish domestic social welfare system. ${ }^{40}$ From the perspective of the MoFLSS, which would be called on to administer it, the program was better called "complementary ESSN" or C-ESSN, to highlight the continuity of the program and the European commitment to funding it. This nomenclature was officially adopted as of January $2021 .{ }^{41}$

This debate over labels was symptomatic of deeper disagreement over funding and, more generally, responsibility. Multiple interviews suggested that Turkish support for ESSN was inextricably linked to the Readmission Agreement. EU Burden-sharing, in this perspective, must continue as long as the agreement remained in place. ${ }^{42}$

\subsection{Beyond the Emergency: Two Contrasting "Exit Strategies"}

Beyond the EU-Turkey tension over whether and how CT for SuTP should be more deeply integrated into the Turkish social assistance system-and who should pay for it - two divergent strategies for more radical change illustrated the extent of uncertainty. Each of these sought to end the ESSN program as it had existed since December 2016. While one proposed to use support payments as incentives for SuTP to begin returning to Syria, the second accepted the long-term presence of Syrians in Turkey and sought to support their integration into the labor force. In both cases, the existing CT system would be used both for transitional assistance and as an incentive for desired action.

\footnotetext{
${ }^{40}$ https://ec.europa.eu/neighbourhoodenlargement/sites /near/files / annexes/c_2019_5454_f1_annex_en_v2_p1_1040405.pdf.

${ }^{41}$ This point was made in a public statement by the Vice President of the MoFLSS, as reported in Milliyet, 17 December 2020. https://www.milliyet.com.tr/ekonomi/abdenturkiyedeki-siginmacilara-yonelik-780-milyon-euroluk-destek-6382340. The program under this new name was signed on that day and went into effect on 1 January 2021. https://www.kizilay.org.tr/Upload/Dokuman/Dosya/january-2021-syria-crisis-humanitarian-relief-operation-09-03-2021-41886931.pdf.

${ }^{42}$ Multiple interviews, 2019 and 2020.
} 


\subsubsection{CT as an Incentive for Repatriation}

As of 2020, AFAD estimated that 150,000 Syrians had permanently returned to Syria since 2017 (in northern areas where there is a Turkish military presence).$^{43}$ In a 2018 speech, President Erdoğan announced his government's intention "...to secure all Syrian lands and ensure that all our guests return to their homes" 44 While no significant move in that direction was evident in the two years that followed, the possibility of using the Red Crescent Card as an instrument for repatriation was evoked in a 2020 interview with a TRC official.

We can include a monetary incentive to return to Syria in the amounts transferred through the TRC card... we already used this kind of incentive to encourage people to move out of the camps. There are many PTT banks in Idlib and Afrin (in Syria), we can open more ATMs over there if needed. The people who go there can collect their cash. Return can become a condition. This is not an issue for this year, but for years to come. We are thinking about using TRC cards as part of a scenario for returning to Syria. ${ }^{45}$

This approach also sought explicitly to ground planning about forced migrants in the broader context of historic Turkish migration policy. The centrality of this was emphasized by officials, who insisted that ESSN must ultimately be compatible with the national migration system. ${ }^{46}$ While we have had occasion to note changes in the past decades, it remains that Turkish migration policy has never defined migrant integration from the perspective of creating a cosmopolitan community with equal rights. To date, efforts at longer-term integration have been limited to migrants of higher socioeconomic status or with Turkish ethnic or linguistic origins (Ark-Yıldırım and Özer-Yürür 2019). The explicit designation of migrants' status as temporary, in this context, takes on renewed importance, and repatriation is put forward as a rational next step.

\footnotetext{
${ }^{43}$ https://www.hurriyetdailynews.com/some-150-000-syrians-have-returned-fromturkey-131108

${ }^{44}$ Author's translation of "Seçimin ardından tüm Suriye topraklarını güvenli hale getirmeyi ve misafirlerimizin tamamının evlerine dönmelerini sağlamayı hedefliyoruz." https://www. haberturk.com/ankara-haberleri/15742051-erdogan-secimin-ardindan-tum-suriye-topraklariniguvenli-hale-getirmeyi-ve-misafirlerimizin.

${ }^{45}$ Interview, 2020.

${ }^{46}$ Interview, 2020.
} 


\subsubsection{CT and the Transition to Formal Employment}

A very different "exit strategy" was also being considered by both Turkish and international agencies, one premised on the prospect of eventually integrating a significant Syrian population for the longer term through gradual inclusion in the Turkish labor market. This strategy was premised on accepting the longer-term presence of Syrians on Turkish soil and gradually transforming them from recipients of aid into productive members of the economy. The 2018 "exit strategy from the ESSN program" report states that while direct assistance was required in the early phases of forced migration: ${ }^{47}$

it is considered that it is the right time to incline for SuTP to labour market in a formal way with better skills and competences. Thus, it is believed that dependence of SuTP on social assistance will be lessened to a certain extent. Secondly, it is observed that SuTP are informally employed in the Turkish labour market. However, the entitlements derived from social assistance scheme makes transition from informality to formality more difficult. It is utmost necessary to manage a balance between conditions of social assistance scheme and formally employment for SuTP. (Presidency and MoFLSS 2018)

An initial $€ 50$ million package of active labor market measures was financed by the first tranche of the FRiT. Building on this base in the second tranche of FRiT, DG-NEAR put together a package of measures collectively worth $€ 465$ million as part of joint projects with international partners and the Turkish Employment Agency (İŞKUR) to help skilled and semi-skilled people improve job and language skills through vocational training. Initial projects signed in December 2019 involved Expertise France and the International Center for Migration Policy Development (European Commission 2020: 12-13). This was intended to take its place in a gradual policy of transition through work incentives. Although open in principle to all registered forced migrants, it was expected that this aid would go primarily to existing ESSN beneficiaries (Revel 2020: 7-8). The role of İŞKUR, using a system already in place for Turkish citizens, is to act as a clearing house. Program participants, like

\footnotetext{
${ }^{47}$ Turkish and international officials interviewed suggested that this report represents above all the point of view of the Directorate of International Labor Force within the MoFLSS.
} 
Turkish recipients of social aid, would go to İŞKUR to apply for a formal job. For the first year of employment, CT would continue. ${ }^{48}$

Implementation of this policy, however, seemed problematic for a number of reasons; integration of labor does not depend only on the social aid mechanism. The overall employment rate in Turkey is relatively low and it is estimated that, for Turkish citizens, one-third of employment is in the informal sector. Under these conditions, the overall efficiency of İŞKUR in matching Turkish workers with jobs has been limited (Yilmaz 2019: 730). For refugees, an additional barrier is obtaining the right to work at all. Turkey granted Syrian under temporary protection the right to work only in 2016, but only subject to a number of conditions:

- To be eligible for formal employment a Syrian under temporary protection must have been registered in TPS for at least 6 months. ${ }^{49}$ For those under the conditional refugee status, the relevant date is six months after application. ${ }^{50}$ Only for those with legally recognized refugee or subsidiary protection status is the right to work permanent. ID card serves as proof of this. ${ }^{51}$

- Employers must apply for work permit on behalf of any foreigners.

- For persons under TPS, work permits must be renewed annually.

- There is a quota for SuTPS in a given workplace: maximum 10\% of total workers. ${ }^{52}$ An additional quota of $5 \%$ is available for persons under International Protection. ${ }^{53}$

- Foreigners are not allowed to work in certain professions (such as lawyers, veterinarian, etc.) ${ }^{54}$ others require prior official permission (health, education services providers).

\footnotetext{
${ }^{48}$ Interview, 2020.
}

${ }^{49}$ https://www.ailevecalisma.gov.tr/media/6360/gecicikoruma.jpg.

${ }^{50}$ www.ailevecalisma.gov.tr/uigm/yabancilar/uluslararasi-koruma-saglanan-yabancilar/

${ }^{51}$ www.ailevecalisma.gov.tr/uigm/yabancilar/uluslararasi-koruma-saglanan-yabancilar/

${ }^{52}$ http://calismaizni.gov.tr/calisma-izni-hakkinda/gecici-koruma/

${ }^{53}$ https: / $/$ www.google $\cdot \operatorname{com} /$ url? sa $=t \& r c t=j \& q=\& e s r c=s \& s o u r c e=w e b \& c d=\& v e d=2 a h U$ KEwi4xtTktsfsAhVvC2MBHXK5Dt4QFjABegQIAhAC\&url=https\%3A\%2F\%2Fdata2 . unhcr.org\%2Fen\%2Fdocuments\%2Fdownload\%2F67638\&usg=AOvVaw0DJkRIBPFil 0 zQWVRbHlg9

${ }^{54}$ https://www.ailevecalisma.gov.tr/uigm/calisma-izni/turk-vatandaslarina-hasredilenmeslekler/ 
In addition, formal employment requires employers to pay at least minimum wage and make the mandatory social security contribution. In practice, the number of work permits issued remains limited. For all foreigners it increased from 17,466 in 2011 to 145,233 in 2019 (MoFLSS 2019: 195 ), the last year for which data were available. This is still a small minority of a registered population of over 2 million SuTP of working age. ${ }^{55}$

Looking to the future, the scope of programs aimed at transitions to the formal workforce remains small compared to this potential population. Examples include a project by World Bank "Employment Support Project For Syrians Under Temporary Protection and Host Communities," 56 and one by the FAO "Better Job Opportunities For Syrians and the Host communities," which seeks to enhance the employment prospects of ESSN beneficiaries, but also of host country nationals. This is done by means of "certified vocational training courses in crop production, livestock and food sectors in the rural area," but is projected to create only some 1500 jobs. ${ }^{57}$ In the estimation of a WFP official,

Even IFRC has gone from talking about "graduating" people to employment to talking about "referring" them to employment, that's the only commitment they are making-very few refugees have actually gotten work permits, employers also prefer informal employees. ${ }^{58}$

For this observer, this can be explained in part by economic conditions. "Construction is declining; the hospitality sector is also a big consumer of Syrian labor; so is the textile industry, which is also down." The further downturn of the Turkish and international economy following the Covid-19 virus crisis of 2020 further weakened these same sectors. At the same time, financial and administrative barriers to formal employment persist, since employers must pay for work permit application. In practice, enforcement of the rules requiring workers to have an official permit is uneven. The European Commission, reports that $57 \%$ of ESSN beneficiaries and $67 \%$ of non-beneficiaries defined unskilled labor as their primary income source and estimates that between 750,000 and 950,000 Syrians

\footnotetext{
${ }^{55}$ https://www.goc.gov.tr/gecici-koruma5638, accessed 17.04.2020.

${ }^{56}$ https://www.avrupa.info.tr/en/project/employment-support-project-syrians-undertemporary-protection-and-host-communities-7005

${ }^{57}$ https://www.avrupa.info.tr/en/news/better-job-opportunities-farming-syriansand-host-communities-10098

${ }^{58}$ Interview, 2020.
} 
worked in the informal sector as of 2018 (European Commission 2018: $55 ; 71$ ). The World Bank estimated that in $202086 \%$ of working-age persons in the population of SuTP held some form of informal employment.

\subsection{From Social Assistance to Market Citizenship}

Bringing together these contrasting scenarios for the future of the ESSN allows us to regain a measure of critical and analytical distance from day-today operations of the program, and illustrates a number of more general points. From the humanitarian perspective, the tension between "emergency" and "alchemical" approaches (Barnett 2011) discussed in Chap. 5 is seen to be as much a question of organizational culture as of general philosophy, with DG-ECHO embodying the former approach while DG-NEAR, although avoiding the vocabulary of humanitarianism, was in effect promoting the second. To the extent that these lines were blurred in practice, this was a cause of expressed concern within both agencies, with officials from DG-ECHO emphasizing that "emergency assistance" could not go on indefinitely, while those from DG-NEAR stressed the importance of medium-term capacity building and systemic change. ${ }^{59}$

Where did this leave the recipients of aid? With onward migration ruled out for the foreseeable future and return to Syria at best a long-term objective, the question focused on their future within Turkey. Should social CT be seen as a permanent element in a "citizenship approach to poverty" or, conversely, is it at best a transitional element in a strategy focused on laborforce participation? The debate over the future of the ESSN puts into stark focus both the limits and the imperatives of both options.

We have noted the disparate origins of the Directorates General for Social Services, on the one hand, and International Labor force, on the other hand. It is the viewpoint of the latter that is found in the "exit strategy" report cited above. ${ }^{60}$ Here we find an emphasis on shorter-term entry into the labor force and concerns that ongoing CT will ultimately be a disincentive to work-a distant echo of nineteenth- and twentieth-century debates over "outdoor relief." This view was not universally shared, however. Others pointed out that, even if they reached their targets, projects for formal employment would provide work for a few thousand people, a tiny fraction of those potentially in need of jobs. In this perspective,

\footnotetext{
${ }^{59}$ Multiple interviews, 2020.

${ }^{60}$ Multiple interviews, 2019, 2020.
} 
ongoing CT was a necessary element of the transition to meaningful participation. ${ }^{61}$

From this perspective, the priority was maintaining CT programs into the indefinite future, pinning hopes for inclusion on education and the gradual integration of multigenerational migrant families. With shortterm access to the formal labor market extremely limited, only ongoing support through CT, in this view, could ensure that progress of this sort continued.

While diverging on means, however, these two approaches converge with respect to ultimate ends. The right and the means to engage in buying and selling-what CT programs at their best can ensure-is only one of the entitlements central to an active role in the market. The ability to work, Sens's (1981) "own-labor entitlement," is just as important. Wanting work, however, is not the same as having legal access to it. So long as protecting the domestic labor market takes precedence over incorporating migrants into it, market citizenship is truncated. CT can empower individuals only as consumers, not as workers or producers.

Beyond this debate, and whatever "exit strategy" eventually emerges, a defining feature of the ESSN was ongoing uncertainty, and this was a problem in and of itself. Citizenship-like rights, even if based on a status that is formally defined as temporary, have meaning only if they are perceived as stable at least into the humanly relevant medium term-the time it takes to raise a family, to establish a business, to acquire employable skills. Leisering's (2019: 320) assertion that CT can constitute a "citizenship approach to poverty" makes sense only in such a context. The very real prospect that the future of social support for SuTP may be a victim of the ambiguous consensus at the origin of the ESSN without being replaced by generalized access to the Turkish labor market means that this tenuous extension to forced migrants of the right to that "modicum of economic welfare and security" necessary "to live the life of a civilized being according to the standards prevailing in the society" (Marshall 1950: 11) may prove fleeting.

Bringing these points together with those made earlier in this chapter should not blind us to the contribution made by the ESSN not only to the short-term survival but to the potential for market integration of forced migrants in Turkey. Making good on that potential, however, transforming market-enhancing instruments of social assistance into elements of market citizenship, would require addressing limits and shortcomings evident in this case. 


\section{REFERENCES}

Ark Yıldırım, Ceren, and Yeşim Özer Yürür. 2019. Uluslararası Göçmenlerin Türkiye'ye Uyumu Yasal Düzenlemeler Ne Derece Uyumu/Entegrasyonu Hedefliyor? International Journal of Political Science and Urban Studies 7 (1): 19-41. https://doi.org/10.14782/ipsus.539183.

Baban, Feyzi, et al. 2017. Playing Border Politics with Urban Syrian Refugees Legal Ambiguities, Insecurities, and Humanitarian Assistance in Turkey. Movement 3 (2): 81-102.

Barnett, Michael. 2011. Empire of Humanity: A History of Humanitarianism. Ithaca, USA: Cornell University Press.

Batalla, Laura, and Juliette Tolay. 2018. Toward Long-term Solidarity with Syrian Refugees? Turkey's Policy Response and Challenges. Washington, DC: Atlantic Council.

Buğra, Ayşe and Sinen Adar. 2008. Social Policy Change in Countries Without Mature Welfare States: The case of Turkey. New Perspectives on Turkey 38: 83-106.

DG-ECHO. 2019. Evaluation of the European Union's Humanitarian Response to the Refugee Crisis in Turkey, Final Report. Brussels: European Commission.

European Commission. 2015. EU-Turkey Joint Action Plan. EC Fact Sheet - MEMO $/ 15 / 5860$

- 2018. Technical Assistance to the EU Facility for Refugees in Turkey. https://ec.europa.eu/neighbourhood-enlargement/sites/default/files/ updated_needs_assessment.pdf.

- 2019. SPaN (2019) Case Study: Turkey. Brussels: European Commission.

- 2020. Fourth Annual Report on the Facility for Refugees in Turkey-Com (2020)162. Brussels: European Commission.

IFRC (International Federation of Red Cross and Red Crescent Societies). 2020. Emergency Social Safety Net Issue 4: Juy 2020.

Le Grand, Julian. 2003. Motivation, Agency, and Public Policy: of Knights and Knaves, Pawns and Queens. Oxford; UK: Oxford University Press.

Leisering, Lutz. 2019. The Global Rise of Social Cash Transfers: How States and International Organizations Constructed a New Instrument for Combating Poverty. Oxford, UK: Oxford University Press.

Marshall, Thomas Humphrey. 1950. Citizenship and Social Class. In Citizenship and Social Class and other Essays, ed. T.H. Marshall, 1-75. Cambridge: UK: Cambridge University Press.

Maunder, Nick, et al. 2018. Evaluation of the DG-ECHO Funded Emergency Social Safety Net (ESSN) in Turkey. November 2016-February 2018: Volume I: Final Evaluation Report. Oxford Policy Management.

MoFLSS (Ministry of Family, Labor, and Social Services). 2019. Activity Report for 2019. Ankara: MoFLSS. 
Özer, Yeşim. 2015. Türkiye ve Fransa Örnekleriyle Uluslararast Gö̧ ve Yabancı Düsmanluğı. Istanbul: Derin Yayınevi.

Presidency and MoFLSS (FRiT office of the Presidency of Turkey and Ministry of Family, Labor and Social Services). 2018. Exit Strategy from the ESSN. Ankara: Government of Turkey.

Revel, Bastien. 2020. Turkey's Refugee Resilience: Expanding and Improving Solutions for the Economic Inclusion of Syrians in Turkey. https://www.atlanticcouncil.org/wp-content/uploads/2020/07/Turkey\%E2\%80\%99s-RefugeeResilience-Expanding-and-Improving-Solutions-for-the-Economic-Inclusion-of-Syrians-in-Turkey-Report.pdf.

Sen, Amartya. 1981. Poverty and Famines: An Essay on Entitlement and Deprivation. Oxford, UJ: Oxford University Press.

TRC (Turkish Red Crescent). 2018. KIZILAYKART Bulletin 3 - November 2018. https://cash-hub.org/wp-content/uploads/sites/3/2020/10/3Say Bulten.pdf.

TRC (Turkish Red Crescent) Migration Service Directorate. 2020. Syrian Crises Humanitarian Relief Operation, June 2020 Report. Ankara: TRC.

WFP (World Food Program). 2017. Turkey: ESSN Monitoring Report Quarter 4/2017. https://data2.unhcr.org/en/documents/details/62568.

- 2019a. The Emergency Social Safety Net (ESSN) Helping Refugees in Turkey. https://docs.wfp.org/api/documents/WFP-0000104792/download/

- 2019b. WFP Turkey Country Brief August 2019. https://reliefweb.int/ sites/reliefweb.int/files/resources/2019\%2008\%20Turkey\%20Country\%20 Brief\%20\%20August.pdf

World Bank. 2020. Project Document on Proposed Loan: 17 March 2020. Report PAD3491. Washington DC: International Bank for Reconstruction and Development.

Yllmaz, Volkan. 2019. The Emerging Welfare Mix for Syrian Refugees in Turkey: The Interplay Between Humanitarian Assistance and the Turkish Welfare System. Journal of Social Policy 48 (4): 721-739. 
Open Access This chapter is licensed under the terms of the Creative Commons Attribution 4.0 International License (http://creativecommons.org/licenses/ by $/ 4.0 /$ ), which permits use, sharing, adaptation, distribution and reproduction in any medium or format, as long as you give appropriate credit to the original author(s) and the source, provide a link to the Creative Commons licence and indicate if changes were made.

The images or other third party material in this chapter are included in the chapter's Creative Commons licence, unless indicated otherwise in a credit line to the material. If material is not included in the chapter's Creative Commons licence and your intended use is not permitted by statutory regulation or exceeds the permitted use, you will need to obtain permission directly from the copyright holder. 